\title{
Left Atrial to Femoral Artery Full Cardiopulmonary Bypass: A Novel Technique for Descending and Thoracoabdominal Aortic Surgery
}

\author{
Dimitra Papanikolaou, MD ${ }^{1}$ Chris Savio, BS, CCP ${ }^{1}$ Mohammad A. Zafar, MBBS ${ }^{1}$ Leon Freudzon, MD ${ }^{1}$ \\ Jinlin Wu, MD ${ }^{1}$ Mohamed Abdelbaky, MD ${ }^{1}$ Keith J. Pelletier, MBA, MHS, CCP1 \\ Joelle Buntin, MSN, RN, RN-BC ${ }^{1}$ Thais Faggion Vinholo, BS, MSC ${ }^{1}$ Bulat A. Ziganshin, MD, PhD ${ }^{1,2}$ \\ Brian Schwartz, MS, CCP ${ }^{1}$ John A. Elefteriades, MD, PhD (Hon) ${ }^{1}$ \\ ${ }^{1}$ Aortic Institute at Yale-New Haven Hospital, Yale University School \\ of Medicine, New Haven, Connecticut \\ ${ }^{2}$ Department of Surgical Diseases, Kazan State Medical University, \\ Kazan, Russia \\ Address for correspondence John A. Elefteriades, MD, Aortic Institute \\ at Yale-New Haven, Yale University School of Medicine, Clinic Building \\ CB 317, 789 Howard Avenue, New Haven, CT 06519 \\ (e-mail: john.elefteriades@yale.edu).
}

Int J Angiol 2020;29:19-26.

\author{
Abstract \\ Keywords \\ - descending aortic \\ replacement \\ - thoracoabdominal \\ aortic replacement \\ - cardiopulmonary \\ bypass \\ - left atrial-femoral \\ bypass \\ - aortic surgery \\ - aortic aneurysm
}

Left atrial-femoral artery (LA-FA) bypass with a centrifugal pump and no oxygenator is commonly used for descending and thoracoabdominal aortic (DTAA) operations, mitigating the deleterious effects of cross-clamping. We present our initial experience performing DTAA replacement under LA-FA (left-to-left) cardiopulmonary bypass (CPB) with an oxygenator. DTAA replacement under LA-FA bypass with an oxygenator was performed in 14 consecutive patients (CPB group). The pulmonary vein and femoral artery (or distal aorta) were cannulated and the full CPB machine were used, including oxygenator, roller pump, pump suckers, and kinetically enhanced drainage. The CPB group was compared with 50 consecutive patients who underwent DTAA replacement utilizing traditional LA-FA bypass without an oxygenator (LA-FA group). Perioperative data were collected and statistical analyses were performed. All CPB patients maintained superb cardiopulmonary stability. The pump sucker permitted immediate salvage and return of shed blood. Superb oxygenation was maintained at all times. High-dose full CPB heparin was reversed without difficulty. The CPB group required markedly fewer blood transfusions than the LA-FA group (2.21 vs. 5.88 units, $p<0.004)$. The 30 -day mortality rate was $7.1 \%(n=1)$ and there were no paraplegia cases in the CPB group versus 7 (14\%) deaths and $3(6 \%)$ paraplegia cases in the LA-FA group. Traditional LA-FA bypass without an oxygenator avoids high-dose heparin. In the present era, heparin reversal is more secure. Our experience finds that the novel application of LA-FA CPB with an oxygenator is safe and suggests improved hemodynamics (immediate return of shed blood) and a hemostatic advantage (avoidance of loss of coagulation factors in the cell saver).
Since the pioneering report by Magovern in $1989,{ }^{1}$ left heart bypass with a centrifugal pump and no oxygenator has long been established as the key strategy for distal aortic perfusion during descending and thoracoabdominal aortic (DTAA) replacement operations, mitigating the deleterious effects of the "clamp and sew" technique. ${ }^{2}$ Left heart bypass provides visceral, spinal cord, and lower limb perfusion while the aorta is cross-clamped and requires only low-dose heparinization. However, in this partial bypass circuit, intraoperative blood salvage is accomplished solely by means of a cell saver, published online

December 9, 2019
Copyright $(2020$ by Thieme Medical Publishers, Inc., 333 Seventh Avenue, New York, NY 10001, USA. Tel: +1(212) 760-0888.
DOI https://doi.org/ 10.1055/s-0039-3400479. ISSN 1061-1711. 
which preserves red blood cells but does not prevent loss of platelets, plasma, and coagulation factors. ${ }^{3}$

The full cardiopulmonary bypass (CPB) circuit including the oxygenator, roller pumps, and pump suckers has been proven to maintain oxygenation and hemodynamic stability during cardiac and ascending or descending aortic operations and to provide immediate blood return to the patient, while preserving plasma and clotting factors. ${ }^{3}$ Aomi et al have previously reported a limited experience with DTAA repair using left heart bypass with a centrifugal pump, an oxygenator, and a heat exchanger. ${ }^{4}$ The purpose of this article is to describe our initial experience performing DTAA replacement with a novel perfusion technique of left atrialfemoral artery (LA-FA) or distal aortic full CPB with an oxygenator, roller pump, and pump suckers.

\section{Methods}

The circuit is shown in - Fig. 1. The technique was conceived by our perfusionist (C.S.) after many years of performing conventional LA-FA partial bypass with a centrifugal pump without an oxygenator. One-lung ventilation is instituted. Inflow is taken from the superior or inferior pulmonary vein with a right angle cannula (number 24, Edwards Lifesciences). Kinetic assisted venous (LA) drainage (KAVD) is a technique in which a roller head is used to control the rate of venous flow. A number 24 right angled cannula is connected to a primed $1 / 4$ "line through a roller pump on the heart-lung machine and returned to the venous reservoir. Blood passes through an oxygenator and heat exchanger and is propelled by a roller pump back to the FA. Our perfusionists note that this system provides optimal hemodynamic and circulatory capabilities. Shed blood is automatically and immediately harvested into the pump suckers and returned to the pump. There is no delay in processing through a cell saver device for later transfusion. Also, the perfusionists can adjust the rate of left atrial drainage via roller pump as needed to leave enough blood in the heart to provide the high upper body pressures required to optimize spinal cord perfusion. They can independently adjust the flow through the other roller pump to maintain the desired level of lower body perfusion. This permits immediate, appropriate response to blood loss and other causes of hemodynamic instability.

Full heparinization is used. Flows are adjusted to maintain a good upper body pressure at or above $140 \mathrm{~mm} \mathrm{Hg}$ during the cross-clamp time and to provide 2 to $4 \mathrm{~L}$ lower body perfusion, dependent on body size. Left atrial return is adjusted to maintain these parameters. Immediate harvesting and return of shed blood is accomplished via the pump suckers.

\section{Patient Population}

Fourteen consecutive patients underwent descending or thoracoabdominal aortic replacement under LA-FA (left-left) CPB with an oxygenator (CPB group) between October 2017 and December 2018 at our institution. The CPB group was compared with 50 consecutive patients who underwent DTAA replacement under traditional left heart bypass without an oxygenator from February 2014 to October 2017 (LA-FA group).

Electronic medical records (EMRs) were reviewed to collect patients' demographics and comorbidities, as well as preoperative, intraoperative, and postoperative parameters, outcomes, and complications. Institutional Review Board approval was obtained from Yale University's Human Investigation Committee. Informed consent was waived due to the retrospective nature of the study.

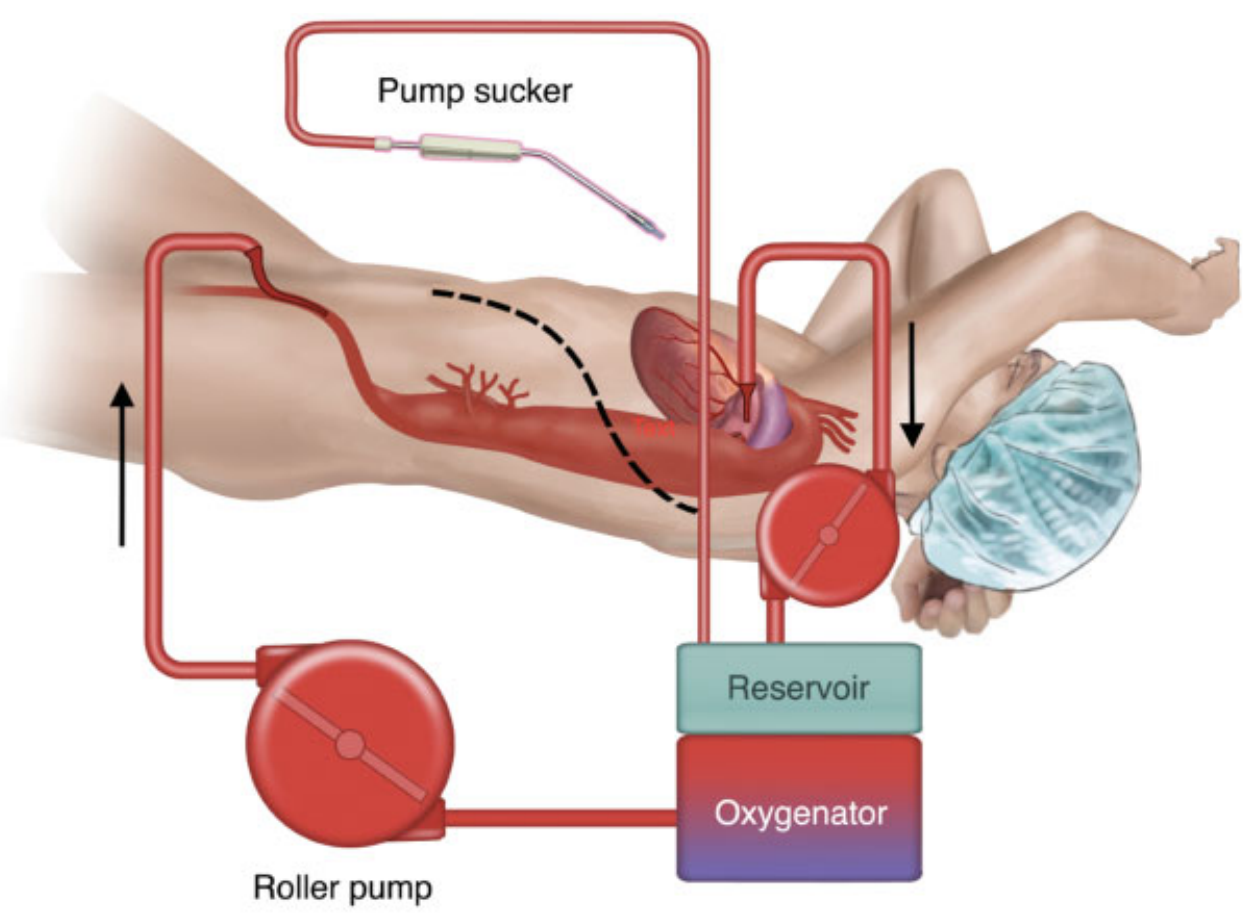

Fig. 1 Left atrial-femoral full cardiopulmonary bypass circuit. 
Table 1 Patient demographics

\begin{tabular}{|l|l|l|l|}
\hline & $\begin{array}{l}\text { CPB group } \\
(\boldsymbol{n}=\mathbf{1 4})\end{array}$ & $\begin{array}{l}\text { LA-FA group } \\
(\boldsymbol{n}=50)\end{array}$ & $\begin{array}{l}\boldsymbol{p} \text {-Value } \\
\text { (if applicable) }\end{array}$ \\
\hline $\begin{array}{l}\text { Age at the } \\
\text { time of } \\
\text { surgery }\end{array}$ & $68.2 \pm 7.2$ & $66.5 \pm 12.7$ & 0.63 \\
\hline $\begin{array}{l}\text { Female } \\
\text { gender }\end{array}$ & $N=3(21.4 \%)$ & $N=27(54 \%)$ & \\
\hline Height $(\mathrm{cm})$ & $173.5 \pm 11.2$ & $168.4 \pm 9.9$ & 0.1 \\
\hline Weight $(\mathrm{kg})$ & $86.07 \pm 16.9$ & $76.7 \pm 17.8$ & 0.08 \\
\hline BMI $\left(\mathrm{kg} / \mathrm{m}^{2}\right)$ & $28.6 \pm 4.7$ & $26.9 \pm 5.1$ & 0.28 \\
\hline
\end{tabular}

Abbreviations: BMI, body mass index; $\mathrm{CPB}$, cardiopulmonary bypass; LA-FA, left atrial-femoral artery.

Statistical analysis was conducted using Fisher's exact test for categorical data and Student's $t$-tests for continuous data. Continuous variables are presented as mean \pm standard deviation and categorical variables are presented as numbers and percentages.

Patient demographics for the two groups are shown in - Table 1. The mean patient age was $68.2 \pm 7.2$ years for the CPB group and $66.5 \pm 12.7$ years for the LA-FA group. Three patients $(21.4 \%)$ in the CPB group and 27 (54\%) patients in the LA-FA group were female. The CPB group consisted of eight (57.1\%) patients with nondissecting aneurysms, four (28.6\%) patients with dissected aneurysms, one (7.1\%) patient with a pseudoaneurysm (as a result of a chronic traumatic aortic transection), and one (7.1\%) patient with penetrating ulcer of the aorta. In the LA-FA group, 27 (54\%) patients presented with nondissecting aneurysms, 22 (44\%) patients with dissected aneurysms, and $1(2 \%)$ patient with contained aortic rupture. Aortic pathology involved only the descending aorta in $3(21.4 \%)$ and 20 (40\%) patients and the thoracoabdominal aorta in 11 (78.6\%) and 30 (60\%) patients in the CPB and LAFA groups, respectively.
The Crawford classification with the Safi modification was used to assess the extent of thoracoabdominal aortic aneurysms, ${ }^{5}$ with the majority of TAAs falling under the most extensive type II category $(N=6$ and $N=10$ for the CPB and LA-FA groups, respectively). The maximal aortic diameter was $5.3 \pm 1 \mathrm{~cm}$ for the $\mathrm{CPB}$ group and $5.8 \pm 1.5 \mathrm{~cm}$ for the LA-FA group (-Table 2 ).

Medical and surgical history for both groups is shown in -Table 3. Comorbidities were more prevalent in the CPB group, as illustrated in - Fig. 2, with the most significant difference observed in coronary artery disease, in 10 (71.4\%) patients in the CPB group and 17 (34\%) patients in the LA-FA group $(p=0.01)$. Six patients in the CPB group ( $42.9 \%)$ had a confirmed family history of thoracic aortic disease as documented by a relative having undergone imaging or surgical repair, versus 9 (18\%) patients in the LA-FA group $(p=0.07)$. Furthermore, 9 (64.3\%) patients in the CPB group and 40 (80\%) patients in the LA-FA group had a prior history of open or endovascular aortic operation. Also, 3 (21.4\%) and 13 (26\%) patients, respectively, had had a previous cardiac surgery (non aortic).

\section{Operative Data}

Operative data are summarized in - Table 4. Descending aortic replacement was performed in 8 (57.1\%) and 32 (64\%) patients and thoracoabdominal aortic replacement was performed in 6 (42.9\%) and 18 (36\%) patients in the CPB and LA-FA groups, respectively. The operation was elective in 13 (92.9\%) and 46 (92\%) patients and urgent in $1(7.1 \%)$ and $4(8 \%)$ patients in the two groups, respectively. Extracorporeal circulation time was $62.5 \pm 27.2$ and $53.6 \pm 23.1$ minutes, respectively $(p=0.23)$. Aortic crossclamp time was higher in the CPB group $(66.9 \pm 24.1$ vs. $50.6 \pm 19$ minutes, $p=0.01)$. The mean arterial blood oxygen saturation $\left(\mathrm{SpO}_{2} \%\right)$ during bypass time was maintained at

Table 2 Diagnosis and related preoperative parameters

\begin{tabular}{|c|c|c|c|}
\hline & CPB group $(n=14)$ & LA-FA group $(n=50)$ & $\begin{array}{l}p \text {-Value } \\
\text { (if applicable) }\end{array}$ \\
\hline $\begin{array}{l}\text { Primary } \\
\text { diagnosis }\end{array}$ & $\begin{array}{l}\text { Nondissecting aneurysm, } N=8(57.1 \%) \\
\text { Dissected aneurysm, } N=4(28.6 \%) \\
\text { - Chronic type A dissection, } N=4(100 \%) \\
\text { Penetrating aortic ulcer, } N=1(7.1 \%) \\
\text { Aortic transection, } N=1(7.1 \%)\end{array}$ & $\begin{array}{l}\text { Nondissecting aneurysm, } N=27(54 \%) \\
\text { Dissected aneurysm, } N=22(44 \%) \\
\text { - Chronic type A dissection, } N=8(36.4 \%) \\
\text { - Type B dissection, } N=14(63.7 \%) \\
\text { (acute/subacute, } N=3 \text {; chronic, } N=11) \\
\text { Contained rupture, } N=1(2 \%)\end{array}$ & \\
\hline $\begin{array}{l}\text { Location of } \\
\text { primary } \\
\text { diagnosis }\end{array}$ & $\begin{array}{l}\text { Thoracoabdominal, } N=11 \text { (78.6\%) } \\
\text { Descending, } N=3(21.4 \%)\end{array}$ & $\begin{array}{l}\text { Thoracoabdominal, } N=30(60 \%) \\
\text { Descending, } N=20(40 \%)\end{array}$ & \\
\hline $\begin{array}{l}\text { Crawford } \\
\text { classification }\end{array}$ & $\begin{array}{l}\text { Crawford } 1, N=3 \\
\text { Crawford 2, } N=6(54.5 \%) \\
\text { Crawford } 4, N=1 \\
\text { Crawford 5, } N=1\end{array}$ & $\begin{array}{l}\text { Crawford } 1, N=11 \\
\text { Crawford } 2, N=10(33.3 \%) \\
\text { Crawford } 3, N=4 \\
\text { Crawford } 4, N=1 \\
\text { Crawford } 5, N=4\end{array}$ & \\
\hline $\begin{array}{l}\text { Maximal } \\
\text { aortic } \\
\text { diameter }\end{array}$ & $5.3 \pm 1$ & $5.8 \pm 1.5$ & 0.2 \\
\hline
\end{tabular}

Abbreviations: CPB, cardiopulmonary bypass; LA-FA, left atrial-femoral artery. 
22 LA-FA CPB with Oxygenator for Aortic Surgery Papanikolaou et al.

Table 3 Previous medical and surgical history of patients in the CPB and LA-FA groups

\begin{tabular}{|l|l|l|l|}
\hline & $\begin{array}{l}\text { CPB } \\
\text { group } \\
(\boldsymbol{n}=14)\end{array}$ & $\begin{array}{l}\text { LA-FA } \\
\text { group } \\
(\boldsymbol{n}=50)\end{array}$ & $p$-Value \\
\hline Hypertension & $14(100 \%)$ & $48(96 \%)$ & 1 \\
\hline Diabetes & $3(21.4 \%)$ & $7(14 \%)$ & 0.68 \\
\hline Dyslipidemia & $9(64.3 \%)$ & $31(62 \%)$ & 0.89 \\
\hline Obesity & $9(64.3 \%)$ & $22(44 \%)$ & 0.75 \\
\hline $\begin{array}{l}\text { Chronic obstructive } \\
\text { pulmonary disease }\end{array}$ & $5(35.7 \%)$ & $12(24 \%)$ & 0.49 \\
\hline Renal failure & $2(14.3 \%)$ & $8(16 \%)$ & 1 \\
\hline $\begin{array}{l}\text { Coronary } \\
\text { artery disease }\end{array}$ & $10(71.4 \%)$ & $17(34 \%)$ & 0.01 \\
\hline $\begin{array}{l}\text { Marfan's syndrome/ } \\
\text { connective } \\
\text { tissue disorder }\end{array}$ & 0 & $3(6 \%)$ & 0.59 \\
\hline History of smoking & $12(85.8 \%)$ & $30(60 \%)$ & 0.11 \\
\hline $\begin{array}{l}\text { Other vascular } \\
\text { abnormality }\end{array}$ & $11(78.6 \%)$ & $39(78 \%)$ & 1 \\
\hline $\begin{array}{l}\text { Previous cardiac } \\
\text { surgery (nonaortic) }\end{array}$ & $3(21.4 \%)$ & $13(26 \%)$ & 1 \\
\hline $\begin{array}{l}\text { Previous aortic } \\
\text { surgery (open) }\end{array}$ & $7(50 \%)$ & $34(68 \%)$ & 0.34 \\
\hline $\begin{array}{l}\text { Previous aortic } \\
\text { endovascular } \\
\text { surgery }\end{array}$ & $4(28.6 \%)$ & $8(16 \%)$ & 0.44 \\
\hline $\begin{array}{l}\text { Confirmed family } \\
\text { history of } \\
\text { aortic disease }\end{array}$ & $6(42.9 \%)$ & $9(18 \%)$ & 0.07 \\
\hline Ahrentins & & & \\
\hline
\end{tabular}

Abbreviations: CPB, cardiopulmonary bypass; LA-FA, left atrial-femoral artery.

Note: The bold values are the ones in which $p<0.05$. high levels in both CPB and LA-FA groups (97.8 \pm 6.8 vs. $97.2 \pm 5, p=0.8$ ).

Patients who underwent DTAA replacement under full left atrial-femoral bypass with an oxygenator required significantly fewer red blood cell (RBC) transfusions intraoperatively than the LA-FA group $(2.21 \pm 3.2$ vs. $5.88 \pm 4.2$ units, $p=0.004$; -Fig. 3). The CPB and LA-FA groups did not substantially differ in platelet transfusions ( $1.29 \pm 1.1$ vs. $1.02 \pm 0.8, p=0.32$ ), fresh frozen plasma/cryoprecipitate transfusions (10 [71.4\%] vs. 44 [88\%] patients, $p=0.21$ ), factor VII transfusions (2 [14.3\%] vs. 2 [4\%] patients, $p=0.21$ ), or bolus inotrope injections intraoperatively ( $2 \pm 1.5$ vs. $1.54 \pm 1.1, p=0.2$ ). However, patients in the $\mathrm{CPB}$ group required significantly more vasopressor infusions in the operating room $(1.93 \pm 0.9$ vs. $0.98 \pm 1, p=0.002)$. Both groups remained hemodynamically stable, as the average total time when the systolic blood pressure was below $80 \mathrm{~mm} \mathrm{Hg}$ intraoperatively was $14.4 \pm 13.8$ minutes for the $\mathrm{CPB}$ group and $16.8 \pm 18.9$ minutes for the LA-FA group $(p=0.66)$. The cell saver volume was significantly reduced in the CPB group $(1,518.6 \pm 1,691.7$ vs. $2,653 \pm 1,805 \mathrm{~mL}, p=0.04)$.

\section{Postoperative Parameters and Operative Outcome}

Total blood loss from arrival at the ICU until 7 a.m. the day following the operation was $1,445.7 \pm 1,061.3 \mathrm{~mL}$ for the $\mathrm{CPB}$ group and $1,094.5 \pm 940.3 \mathrm{~mL}$ for the LA-FA group $(p=0.23$; - Table 5). The mean lowest systolic blood pressure the first night after the operation was $107.1 \pm 14.9 \mathrm{~mm} \mathrm{Hg}$ for the CPB group and $111.7 \pm 18.5$ for the LA-FA group $(p=0.4)$. There was no significant difference observed between the CPB and LA-FA groups in terms of postoperative INR ( $1.41 \pm 0.4 \mathrm{vs}$. $1.32 \pm 0.35, p=0.3)$ and postoperative PTT ( $45.5 \pm 22.1$ vs. $37.7 \pm 19.5, p=0.2)$. The CPB group had significantly lower postoperative $\mathrm{RBC}$ count $(3.3 \pm 0.6$ vs. $4.0 \pm 0.7$ cells $/ \mu \mathrm{L}$, $p=0.0001)$ and hematocrit values ( $30.2 \pm 4.3$ vs. $35.8 \pm 6.2$,

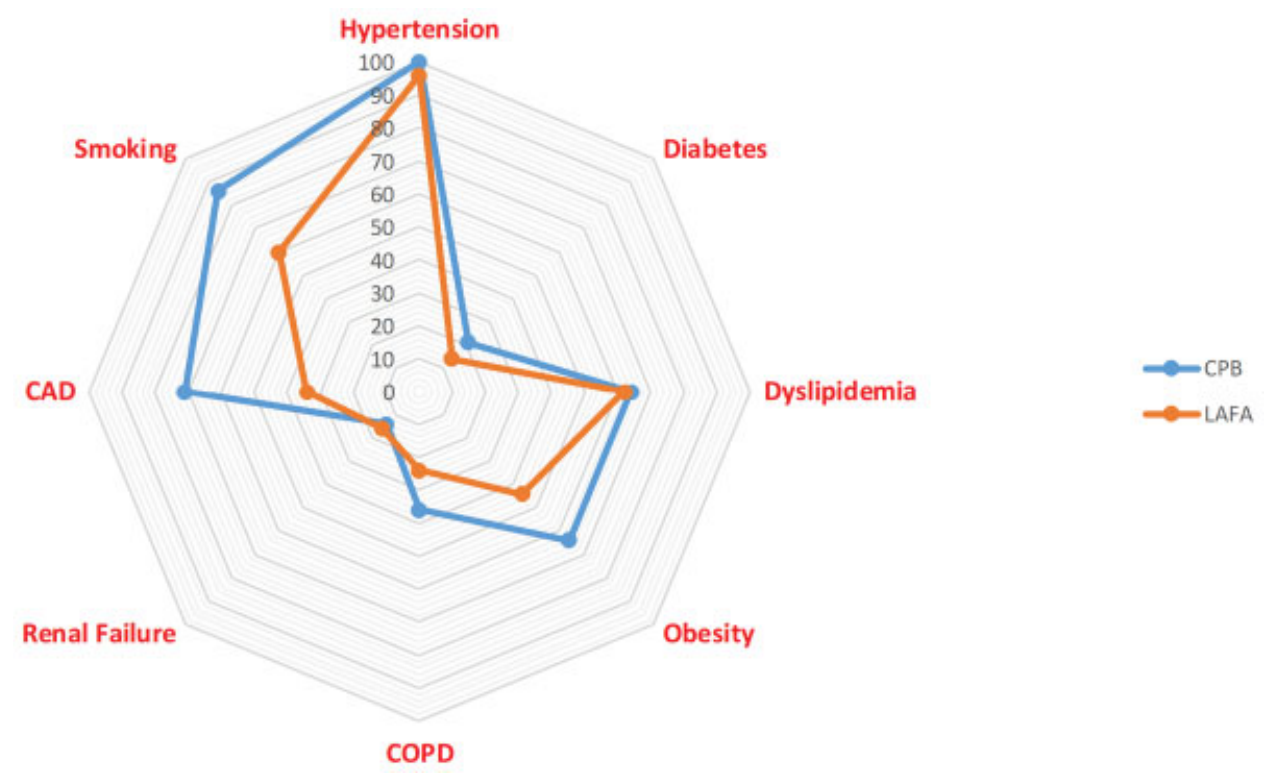

Fig. 2 Radar plot showing patient comorbidities for CPB and LA-FA groups. Note higher complexity of CPB group. CAD, coronary artery disease; COPD, chronic obstructive pulmonary disease; CPB, cardiopulmonary bypass; LA-FA, left atrial-femoral artery. 
Table 4 Operative data for CPB and LA-FA groups

\begin{tabular}{|c|c|c|c|}
\hline & CPB group $(n=14)$ & LA-FA group $(n=50)$ & $\begin{array}{l}p \text {-Value } \\
\text { (if applicable) }\end{array}$ \\
\hline Operation-emergent, urgent, elective & $\begin{array}{l}\text { Elective, } N=13(92.9 \%) \\
\text { Urgent, } N=1(7.1 \%)\end{array}$ & $\begin{array}{l}\text { Elective, } N=46(92 \%) \\
\text { Urgent, } N=4(8 \%)\end{array}$ & \\
\hline $\begin{array}{l}\text { Surgery replacement-descending, } \\
\text { thoracoabdominal }\end{array}$ & $\begin{array}{l}\text { Descending, } N=8(57.1 \%) \\
\text { Thoracoabdominal, } N=6(42.9 \%)\end{array}$ & $\begin{array}{l}\text { Descending, } N=32(64 \%) \\
\text { Thoracoabdominal, } N=18(36 \%)\end{array}$ & \\
\hline Cannulation site (to pump) & Pulmonary vein, $N=14(100 \%)$ & Pulmonary vein, $N=50$ (100\%) & \\
\hline Cannulation site (from pump) & $\begin{array}{l}\text { Femoral artery, } N=6(42.9 \%) \\
\text { Distal aorta, } N=6(42.9 \%) \\
\text { Left iliac artery, } N=2(14.3 \%)\end{array}$ & $\begin{array}{l}\text { Femoral artery, } N=36(72 \%) \\
\text { Distal aorta, } N=13(26 \%) \\
\text { Right iliac artery, } N=1(2 \%)\end{array}$ & \\
\hline $\begin{array}{l}\text { Surgery-additional concomitant } \\
\text { procedure (e.g., wedge lung } \\
\text { resection, subclavian artery } \\
\text { reconstruction, among others) }\end{array}$ & $11(78.6 \%)$ & $31(62 \%)$ & 0.35 \\
\hline Extracorporeal circulation time (min) & $62.5 \pm 27.2$ & $53.6 \pm 23.1$ & 0.23 \\
\hline Aortic cross-clamp time (min) & $66.9 \pm 24.1$ & $50.6 \pm 19$ & 0.01 \\
\hline Mean $\mathrm{SpO}_{2}$ during bypass time (\%) & $97.8 \pm 6.8$ & $97.2 \pm 5$ & 0.8 \\
\hline $\begin{array}{l}\text { Number of RBC units transfused } \\
\text { intraoperatively }\end{array}$ & $2.21 \pm 3.2$ & $5.88 \pm 4.2$ & 0.004 \\
\hline $\begin{array}{l}\text { Number of platelet units } \\
\text { transfused intraoperatively }\end{array}$ & $1.29 \pm 1.1$ & $1.02 \pm 0.8$ & 0.32 \\
\hline $\begin{array}{l}\text { FFP/cryoprecipitate transfused } \\
\text { intraoperatively }\end{array}$ & $N=10(71.4 \%)$ & $N=44(88 \%)$ & 0.21 \\
\hline Factor VII transfused intraoperatively & $N=2(14.3 \%)$ & $N=2(4 \%)$ & 0.21 \\
\hline $\begin{array}{l}\text { Number of vasopressors } \\
\text { infused intraoperatively }\end{array}$ & $1.93 \pm 0.9$ & $0.98 \pm 1$ & 0.002 \\
\hline $\begin{array}{l}\text { Number of bolus inotropes } \\
\text { injected intraoperatively }\end{array}$ & $2 \pm 1.5$ & $1.54 \pm 1.1$ & 0.2 \\
\hline $\begin{array}{l}\text { Total number of minutes when SBP was } \\
\text { below } 80 \mathrm{~mm} \mathrm{Hg} \text { intraoperatively }\end{array}$ & $14.4 \pm 13.8$ & $16.8 \pm 18.9$ & 0.66 \\
\hline Cell saver volume $(\mathrm{mL})$ & $1,518.6 \pm 1,691.7$ & $2,653 \pm 1,805$ & 0.04 \\
\hline $\begin{array}{l}\text { Motor evoked potentials-preserved/ } \\
\text { transient decrease/permanent loss }\end{array}$ & $\begin{array}{l}\text { Preserved, } N=6(42.9 \%) \\
\text { Transient decrease, } N=8(57.1 \%)\end{array}$ & $\begin{array}{l}\text { Preserved, } N=27(54 \%) \\
\text { Transient decrease, } N=15(30 \%) \\
\text { Permanent loss, } N=1(2 \%)\end{array}$ & \\
\hline
\end{tabular}

Abbreviations: CPB, cardiopulmonary bypass; FFP, fresh frozen plasma; LA-FA, left atrial-femoral artery; RBC, red blood cells; SBP, systolic blood pressure; $\mathrm{SpO}_{2}$, peripheral capillary oxygen saturation.

Note: The bold values are the ones in which $p<0.05$.

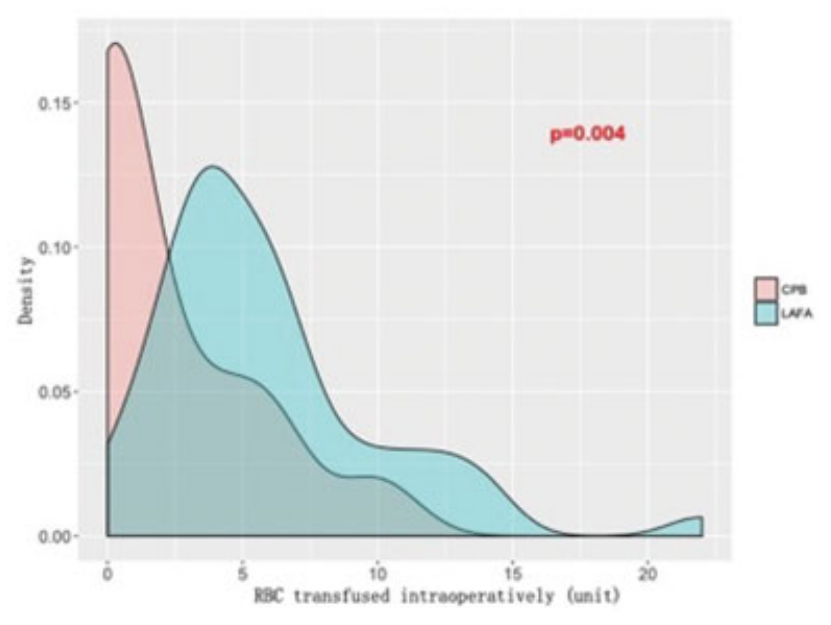

Fig. 3 Kernel density plot of number of intraoperative RBC transfusions in the CPB and LA-FA groups. CPB, cardiopulmonary bypass; LA-FA, left atrial-femoral artery; RBC, red blood cell. $p=0.002$ ). However, these patients did not require a significantly higher amount of transfusions postoperatively, with an average of $3.3 \pm 3.2 \mathrm{RBC}$ units required, as compared with $1.6 \pm 4.4$ RBC units for the LA-FA group $(p=0.19)$, as well as $0.9 \pm 1.1$ versus $1.1 \pm 1.9$ platelet units $(p=0.78)$. Fresh frozen plasma or cryoprecipitate transfusion was required in 8 (57.1\%) and $20(40 \%)$ patients $(p=0.36)$, and factor VII was transfused in $4(28.6 \%)$ and $6(12 \%)$ patients $(p=0.2)$ in the CPB and LA-FA group, respectively.

Postoperative outcomes are summarized in -Table 6 . Patients were followed up clinically at 30 days to assess mortality and duration of hospitalization, as well as postoperative complications. Thirty-day mortality included only one $(7.1 \%)$ patient from the CPB group and seven (14\%) patients from the LA-FA group $(p=0.67)$. No patients in the CPB group suffered paraparesis or paraplegia, compared with three $(6 \%)$ patients in the LA-FA group $(p=0.59)$. Three (21.4\%) patients in the CPB group required a reexploration 
24 LA-FA CPB with Oxygenator for Aortic Surgery Papanikolaou et al.

Table 5 Postoperative parameters for CPB and LA-FA groups

\begin{tabular}{|l|l|l|l|}
\hline & CPB group $(\boldsymbol{n}=\mathbf{1 4})$ & LA-FA group $(\boldsymbol{n}=\mathbf{5 0})$ & $\boldsymbol{p}$-Value (if applicable) \\
\hline $\begin{array}{l}\text { Total blood loss until 7 a.m. on } \\
\text { postoperative day 1 }(\mathrm{mL})\end{array}$ & $1,445.7 \pm 1,061.3$ & $1,094.5 \pm 940.3$ & 0.23 \\
\hline Lowest SBP the night after surgery & $107.1 \pm 14.9$ & $111.7 \pm 18.5$ & 0.4 \\
\hline $\begin{array}{l}\text { Number of vasopressors infused on } \\
\text { the first postoperative night }\end{array}$ & $0.9 \pm 1.2$ & $0.5 \pm 0.8$ & 0.14 \\
\hline Temperature at ICU arrival & $35.9 \pm 1.1$ & $35.8 \pm 0.8$ & 0.65 \\
\hline Postoperative INR & $1.41 \pm 0.4$ & $1.32 \pm 0.35$ & 0.4 \\
\hline Postoperative PTT & $45.5 \pm 22.1$ & $37.7 \pm 19.5$ & 0.2 \\
\hline Postoperative RBC count & $3.3 \pm 0.6$ & $4.0 \pm 0.7$ & $\mathbf{0 . 0 0 0 1}$ \\
\hline Postoperative hematocrit & $30.2 \pm 4.3$ & $35.8 \pm 6.2$ & $\mathbf{0 . 0 0 2}$ \\
\hline Number of RBC units transfused postoperatively & $3.3 \pm 3.2$ & $1.6 \pm 4.4$ & 0.19 \\
\hline Number of platelet units transfused postoperatively & $0.9 \pm 1.1$ & $1.1 \pm 1.9$ & 0.78 \\
\hline Fresh frozen plasma transfused postoperatively & $N=8(57.1 \%)$ & $N=20(40 \%)$ & 0.36 \\
\hline Factor VII transfused postoperatively & $N=4(28.6 \%)$ & $N=6(12 \%)$ & 0.2 \\
\hline
\end{tabular}

Abbreviations: CPB, cardiopulmonary bypass; ICU, intensive care unit; INR, international normalized ratio; LA-FA, left atrial-femoral artery; PTT, partial thromboplastin time; RBC, red blood cells; SBP, systolic blood pressure.

Note: The bold values are the ones in which $p<0.05$.

Table 6 Early mortality, morbidity, and hospital stay duration for CPB and LA-FA groups

\begin{tabular}{|l|l|l|l|}
\hline & $\begin{array}{l}\text { CPB group } \\
(\boldsymbol{n}=\mathbf{1 4})\end{array}$ & $\begin{array}{l}\text { LA-FA group } \\
(\boldsymbol{n}=\mathbf{5 0})\end{array}$ & $p$-Value \\
\hline 30 -d mortality & $1(7.1 \%)$ & $7(14 \%)$ & 0.67 \\
\hline Stroke & $1(7.1 \%)$ & $4(8 \%)$ & 1 \\
\hline Paraplegia & 0 & $3(6 \%)$ & 0.59 \\
\hline Seizures & 0 & 0 & 1 \\
\hline Atrial fibrillation & $7(50 \%)$ & $10(20 \%)$ & 0.04 \\
\hline $\begin{array}{l}\text { Prolonged } \\
\text { ventilation ( }>48 \mathrm{~h})\end{array}$ & $2(14.3 \%)$ & $9(18 \%)$ & 1 \\
\hline $\begin{array}{l}\text { Pulmonary } \\
\text { complications }\end{array}$ & $5(35.7 \%)$ & $17(34 \%)$ & 1 \\
\hline $\begin{array}{l}\text { Renal dysfunction } \\
\text { requiring CRRT } \\
\text { or dialysis }\end{array}$ & $2(14.3 \%)$ & $4(8 \%)$ & 0.6 \\
\hline $\begin{array}{l}\text { Reexploration } \\
\text { for bleeding }\end{array}$ & $3(21.4 \%)$ & $3(6 \%)$ & 0.11 \\
\hline $\begin{array}{l}\text { Hospital stay } \\
\text { duration (d) }\end{array}$ & $15.7 \pm 10$ & $11.9 \pm 9.4$ & 0.2 \\
\hline
\end{tabular}

Abbreviation: CCRT, continuous renal replacement therapy; CPB, cardiopulmonary bypass; LA-FA, left atrial-femoral artery.

Note: The bold values are the ones in which $p<0.05$.

operation for bleeding, compared with three (6\%) patients in the LA-FA group $(p=0.11)$. Other postoperative morbidities for the CPB and LA-FA groups, respectively, included stroke in $1(7.1 \%)$ and $4(8 \%)$ patients, atrial fibrillation in 7 (50\%) and $10(20 \%)$ patients $(p=0.04)$, prolonged ventilation (more than 48 hours) in $2(14.3 \%)$ and 9 (18\%) patients, pulmonary complications in 5 (35.7\%) and 17 (34\%) patients, and renal dysfunction requiring dialysis in $2(14.3 \%)$ and 4 (8\%) patients $(p=0.6)$. Average hospital stay duration was $15.7 \pm 10$ days for the CPB group and $11.9 \pm 9.4$ days for the LA-FA group $(p=0.2)$.

The surgeon's intraoperative strong impression was that hemodynamics and oxygenation were easily maintained, likely reflecting immediate harvesting and transfusion of shed blood.

\section{Discussion}

Despite the progress in DTAA surgery, the appropriate perfusion strategies for preventing severe complications such as spinal cord ischemia and end-organ dysfunction remain controversial. Some studies have shown that left heart bypass has reduced incidence of paraparesis and paraplegia from 39 to $10 \%$ in type II cases and has led to a significant decrease in postoperative renal failure. ${ }^{6-10}$ Others have demonstrated that left heart bypass produces no concrete advantage over the "clamp and sew" technique, especially in terms of spinal cord injury. ${ }^{11,12}$ Some authors have also reported favorable outcomes with the routine use of full arteriovenous $\mathrm{CPB}^{13}$ and total circulatory arrest ${ }^{14}$ during DTAA repair.

In our experience, left atrial-femoral bypass with an oxygenator is safe and represents an interesting alternative to traditional left heart bypass during DTAA operations. The merits and demerits of the novel perfusion technique compared with conventional left heart bypass are shown in -Table 7. All patients remained hemodynamically stable intraoperatively, as the use of the cardiotomy reservoir and the pump suckers permitted blood salvage and immediate return to the patient. Kinetically enhanced drainage permitted excellent hemodynamic modulation. Full-dose CPB heparin was reversed without difficulty and there were no CPB circuit-related intraoperative complications. 
Table 7 Merits and demerits of novel perfusion with roller pump and oxygenator, compared with conventional LA-FA bypass

\begin{tabular}{|l|l|}
\hline CPB (LA-FA with oxygenator) & Conventional LA-FA bypass (no oxygenator) \\
\hline Benefits & $\begin{array}{l}\text { Delay in return of shed blood due } \\
\text { to cell saver processing }\end{array}$ \\
\hline Immediate harvest and return of shed blood & $\begin{array}{l}\text { Loss of coagulation components in } \\
\text { plasma removed by cell saver }\end{array}$ \\
\hline $\begin{array}{l}\text { Preservation of coagulation components } \\
\text { lost in plasma removal by cell saver }\end{array}$ & No contribution to oxygenation \\
\hline Oxygenation of desaturated blood from “down” lung & \\
\hline $\begin{array}{l}\text { Smooth, secure hemodynamics } \\
\text { (strong clinical impression) }\end{array}$ & None \\
\hline “Kinetically enhanced" drainage & Low-dose heparinization \\
\hline Liabilities & Simplicity \\
\hline Full heparinization & \\
\hline Increased complexity &
\end{tabular}

Abbreviations: CPB, cardiopulmonary bypass; LA-FA, left atrial-femoral artery.

Aomi and colleagues have previously reported their experience performing DTAA replacement using a centrifugal pump (ours was a roller pump), an oxygenator and a heat exchanger in 25 patients and standard left heart bypass in 45 patients. The authors demonstrated that the group with the oxygenator experienced significantly less intraoperative blood loss $(p<0.01)$ and required significantly fewer blood transfusions $(p<0.05)$. Thus, their experience was similar to ours. Our experience also showed that the CPB group required significantly fewer RBC transfusions compared with the LA-FA group ( 2.21 vs. $5.88, p=0.004$; - Fig. 3 ). These patients also had markedly reduced cell saver volume (1,518.6 vs. $2,653 \mathrm{~mL}, p=0.04)$, confirming the salvage of plasma through the use of the full heart-lung machine. Aomi et al also reported that their method showed an oxygenation advantage; patients in our CPB group also maintained superb oxygenation at all times. ${ }^{4}$ We felt that directly draining and oxygenating desaturated blood from the "down" lung produced reliable and beneficial high oxygenation.

In our series, the patients in the CPB group presented with greater comorbidities than the LA-FA group ( - Fig. 2), with the largest difference observed in coronary artery disease $(p=0.01)$. A study by Coselli et al evaluating the outcomes of DTAA replacement in 3,309 patients showed that coronary artery disease increases risk of paraplegia and paraparesis in Crawford type I and II repairs, ${ }^{15}$ such as the cases performed in the majority of patients in our CPB group. Furthermore, the CPB group had significantly longer aortic cross-clamp times $(66.9 \pm 24.1$ vs. $50.6 \pm 19$ minutes, $p=0.01)$, likely indicating increased operation complexity in this group. Despite the greater burden of CAD and more complex surgical procedures, not a single case of paraplegia was observed in this group, which could be interpreted as a benefit of the novel full LA-FA bypass technique. Reliably superb oxygenation maintenance may contribute to cord protection. Early mortality included only one complex patient in the $\mathrm{CPB}$ group (7.1\%) and 7 patients (14\%) in the LA-FA group, indicating excellent safety for the novel full LA-FA bypass technique.

\section{Study Limitations}

We have presented a favorable but limited experience with the novel technique of left atrial-femoral CPB with an oxygenator for DTAA surgery. More cases and a longer follow-up are necessary to ascertain more fully the benefits and disadvantages of this perfusion strategy for DTAA replacement. We did not compare with full CPB with drainage from the right atrium, which has been used for decades in such operations but fallen behind in usage after the advent of LA-FA bypass with a centrifugal pump. Our technique avoids the need for groin dissection and passage of a long venous line to the RA. Also, with full bypass, issues of cardioplegia and upper and lower body arterial cannulation may arise, depending on team preferences and policies.

\section{Conclusion}

Traditional LA-FA bypass without an oxygenator avoids high-dose heparin. Our experience finds that in the present era, when heparin reversal is more secure, application of full left atrial-femoral bypass with an oxygenator is safe. This novel technique, which includes a venous reservoir, a roller pump with pump suckers, and an oxygenator, permits immediate blood retrieval and salvage of the plasma and coagulation factors lost in the cell saver with the traditional LA-FA bypass, while maintaining arterial oxygenation levels. Our initial clinical impression is that the novel CPB technique with an oxygenator provides significant advantages, and we suggest that surgeons explore this technical option.

Source of Funding

None.

Conflict of Interest

The authors report no conflict of interest relative to this work. 


\section{References}

1 Benckart DH, Magovern GJ, Liebler GA, et al. Traumatic aortic transection: repair using left atrial to femoral bypass. J Card Surg 1989;4(01):43-49

2 Ziganshin BA, Elefteriades JA. Surgical management of thoracoabdominal aneurysms. Heart 2014;100(20):1577-1582

3 Bassin L, Bell D. Temporary extracorporeal bypass modalities during aortic surgery. Best Pract Res Clin Anaesthesiol 2016;30(03):341-357

4 Aomi S, Hashimoto A, Tagusari O, et al. A new supportive method for aortic aneurysm surgery: centrifugal left heart bypass combined with an oxygenator and a heat exchanger. Artif Organs 1996;20(05):700-703

5 Safi HJ, Winnerkvist A, Miller CC III, et al. Effect of extended crossclamp time during thoracoabdominal aortic aneurysm repair. Ann Thorac Surg 1998;66(04):1204-1209

6 Conrad MF, Ergul EA, Patel VI, et al. Evolution of operative strategies in open thoracoabdominal aneurysm repair. J Vasc Surg 2011;53(05):1195-1201.e1

7 Safi HJ, Miller CC III, Huynh TT, et al. Distal aortic perfusion and cerebrospinal fluid drainage for thoracoabdominal and descending thoracic aortic repair: ten years of organ protection. Ann Surg 2003;238(03):372-380, discussion 380-381

8 Read RA, Moore EE, Moore FA, Haenel JB. Partial left heart bypass for thoracic aorta repair. Survival without paraplegia. Arch Surg 1993;128(07):746-750, discussion 750-752
9 Biglioli P, Spirito R, Agrifoglio M, et al. Surgery of descending thoracic aortic aneurysms with centrifugal pump support. Cardiovasc Surg 1997;5(01):99-103

10 Estrera AL, Miller CC III, Chen EP, et al. Descending thoracic aortic aneurysm repair: 12-year experience using distal aortic perfusion and cerebrospinal fluid drainage. Ann Thorac Surg 2005;80(04): 1290-1296, discussion 1296

11 Coselli JS, LeMaire SA, Conklin LD, Adams GJ. Left heart bypass during descending thoracic aortic aneurysm repair does not reduce the incidence of paraplegia. Ann Thorac Surg 2004;77 (04):1298-1303, discussion 1303

12 Svensson LG, Crawford ES, Hess KR, Coselli JS, Safi HJ. Experience with 1509 patients undergoing thoracoabdominal aortic operations. J Vasc Surg 1993;17(02):357-368, discussion 368-370

13 Kouchoukos NT, Masetti P, Rokkas CK, Murphy SF, Blackstone EH. Safety and efficacy of hypothermic cardiopulmonary bypass and circulatory arrest for operations on the descending thoracic and thoracoabdominal aorta. Ann Thorac Surg 2001;72(03):699-707, discussion 707-708

14 Soukiasian HJ, Raissi SS, Kleisli T, et al. Total circulatory arrest for the replacement of the descending and thoracoabdominal aorta. Arch Surg 2005;140(04):394-398

15 Coselli JS, LeMaire SA, Preventza O, et al. Outcomes of 3309 thoracoabdominal aortic aneurysm repairs. J Thorac Cardiovasc Surg 2016;151(05):1323-1337 